\title{
Editorial
}

\section{Psychological and Behavioral Aspects of Sustainability}

\author{
Susan M. Koger \\ Department of Psychology, Willamette University, 900 State Street, Salem, Oregon 97301, USA; \\ E-Mail: skoger@willamette.edu
}

Received: 5 July 2013 / Accepted: 8 July 2013 / Published: 10 July 2013

I am honored to introduce this special issue of Sustainability, which exemplifies how the field of Psychology can contribute to multi- and inter-disciplinary efforts to create a sustainable society. In fact, achieving the goal of environmental, economic, and social sustainability is predicated on changing human behavior; the purview of Psychologists (reviewed in [1], see also [2-7]).

So-called "environmental problems" are really problems of human behavior, caused by collective human actions and their underlying thoughts, beliefs, feelings, and values [1]. Consequently, research from various sub-fields of psychology can

- Aid an understanding of the drivers of non-sustainable behaviors;

- Identify barriers to more sustainable behaviors;

- Inform strategies for motivating change and encouraging pro-environmental action;

- Enhance communication between experts, legislators, and lay audiences concerning environmental issues;

- Inspire educators in improving environmental education curricula;

- Contribute to policy development, implementation, and enforcement; and

- Reveal human factors contributing to the likely success — or failure —of nascent technologies.

As Newton and Meyer [8] argue in their contribution to this issue, individual and household behavior changes offer the potential "for a much faster rate of sustainability transformation than supply-side technological innovation of key infrastructures and services" (p. 1212). Yet despite this burgeoning work, the importance of incorporating Psychology in Sustainability/Environmental Studies curricula, as well as educating Psychology students about real-world environmental challenges, frequently goes unrecognized in both the U.S. [9] and Australia [10].

Osbaldiston [11] provides an overview and some applications of the theoretical and empirical work within the field that has come to be known as Conservation Psychology [12]. He notes that despite several decades of work focusing on the adverse impacts of human behavior, there appears to be a significant disconnect between theoretical models and empirical research related to environmentally relevant behaviors. This observation may inspire researchers to 
- more directly test predictions arising from current theoretical models,

- gather data on actual behavior rather than relying on self-reports, and perhaps most importantly,

- conduct research on those behaviors with the greatest environmental impact (e.g., transportation choices, particularly in the U.S.) rather than those that are more expedient (recycling, turning off lights).

We appreciate the efforts of the contributors to this special issue who are addressing some of these issues, including the apparent gap between people's attitudes, intentions, and relevant actual behaviors [8]. The study contributed by de Groot, Abrahamse, and Jones [13] demonstrates that interventions that increase the salience of personal and injunctive norms (what is expected or approved of in a particular situation) can reduce consumption of plastic bags and other resources.

Tapia-Fonllem and his colleagues [14] identified several components of sustainable behaviors, including pro-ecological, frugal, altruistic, and equitable actions, all of which were related to an individual's intention to act as well as his/her happiness and subjective well-being. Venhoeven, Bolderdijk and Steg [15] provide an important distinction between hedonic and eudaimonic well-being that will not only assist in the framing of empirical work, but also in understanding apparent contradictions in the earlier literature. Their analysis suggests that if people feel that they have the choice to engage in behaviors that they perceive to be morally right and to be making a positive difference, they are more likely to derive a sense of personal meaning (eudaimonic well-being) from such actions. Similar relationships between the use of meaning-focused coping styles and positive affect, life-satisfaction and optimism were observed by Ojala [16] in a sample of young people.

Younger citizens represent an important population with respect to sustainability efforts, as they will soon be in leadership positions and will also bear the brunt of the adverse impacts of climate change and other environmental stressors. Bloodhart, Swim, and Zawadski [17] demonstrated the efficacy of a program where college students worked to identify potential obstacles to changing their own behavior in a pro-environmental direction (pro-active coping), and then encouraged such change in their peers.

I am grateful to the Editorial Board of Sustainability as well as all contributing authors for bringing attention to the myriad ways we can foster our own collective sense of eudaimonic well-being, as we work together to address and mitigate the serious contemporary challenges to a sustainable society.

\section{References}

1. Koger, S.M.; Winter, D.D. The Psychology of Environmental Problems: Psychology for Sustainability; Psychology Press: New York, NY, USA, 2010.

2. Clayton, S.; Myers, G. Conservation Psychology: Understanding and Promoting Human Care for Nature, 1st ed; Wiley: Hoboken, NJ, USA, 2009; p. 263.

3. Gifford, R. Environmental psychology and sustainable development: Expansion, maturation, and challenges. J. Soc. Iss. 2007, 63, 199-212.

4. Kazdin, A.E. Psychological science's contributions to a sustainable environment: Extending our reach to a grand challenge of society. Am. Psychol. 2009, 64, 339-356. 
5. Koger, S.M.; Leslie, K.E.; Hayes, E.D. Climate change: Psychological solutions and strategies for change. Ecopsychology 2011, 3, 227-235.

6. Pratarelli, M.E. When human nature confronts the need for a global environmental ethics. JSEC 2012, 6, 384-403.

7. Swim, J.K.; Stern, P.C.; Doherty, T.J.; Clayton, S.; Reser, J.P.; Weber, E.U.; Gifford, R.; Howard, G.S. Psychology's contributions to understanding and addressing global climate change. Am. Psychol. 2011, 66, 241-250.

8. Newton, P.; Meyer, D. Exploring the attitudes-action gap in household resource consumption: Does "environmental lifestyle" segmentation align with consumer behaviour? Sustainability 2013, $5,1211-1233$.

9. Koger, S.M.; Scott, B.A. Psychology and environmental sustainability: A call for integration. Teach. Psychol. 2007, 34, 10-18.

10. Pearson, E. Conservation psychology: A gap in current Australian undergraduate Psychology education? Sustainability 2013, 5, 1266-1281.

11. Osbaldiston, R. Synthesizing the experiments and theories of Conservation Psychology. Sustainability 2013, 5, 2770-2795.

12. Saunders, C.D. The emerging field of Conservation Psychology. Hum. Ecol. Rev. 2003, 10, 137-149.

13. De Groot, J.; Abrahamse, W.; Jones, K. Persuasive normative messages: The influence of injunctive and personal norms on using free plastic bags. Sustainability 2013, 5, 1829-1844.

14. Tapia-Fonllem, C.; Corral-Verdugo, V.; Fraijo-Sing, B.; Durón-Ramos, M. Assessing sustainable behavior and its correlates: A measure of pro-ecological, frugal, altruistic and equitable actions. Sustainability 2013, 5, 711-723.

15. Venhoeven, L.; Bolderdijk, J.; Steg, L. Explaining the paradox: How pro-environmental behaviour can both thwart and foster well-being. Sustainability 2013, 5, 1372-1386.

16. Ojala, M. Coping with climate change among adolescents: Implications for subjective well-being and environmental engagement. Sustainability 2013, 5, 2191-2209.

17. Bloodhart, B.; Swim, J.; Zawadzki, M. Spreading the eco-message: Using proactive coping to aid eco-rep behavior change programming. Sustainability 2013, 5, 1661-1679.

(C) 2013 by the authors; licensee MDPI, Basel, Switzerland. This article is an open access article distributed under the terms and conditions of the Creative Commons Attribution license (http://creativecommons.org/licenses/by/3.0/). 